\title{
UJI DOSIS TRICHOKOMPOS PADA BERBAGAI KOMPOSISI GAMBUT TERHADAP PERTUMBUHAN DAN HASIL BAWANG MERAH (Allium ascalonicum $\mathbf{L}$ )
}

\author{
Trichocompos Dose Test on Various Compositions of Peat on Growth \\ and Production of Shallots (Allium ascalonicum L.)
}

\author{
Selvia Sutriana dan Saripah Ulpah \\ Dosen Prodi Agroteknologi Fakultas Pertanian Universitas Islam Riau \\ Email: selviasutriana@agr.uir.ac.id \\ [Diterima: Februari 2019; Disetujui: Maret 2019]
}

\begin{abstract}
ABSTRAK
The cultivation of shallots in peat is constrained by the low level of soil fertility and one of methods to increase the nutrient content is by applying trichocompost. Trichokompos is material from plant residues that are composted and mixed with Trichoderma sp. as decomposers. Trichocompost improves soil fertility (soil biology, physics, and chemistry). The purpose of this study was to determine the effect of trichocompost doses on various peat compositions on the yield of shallots. Research was conducted at the Experimental farm of Faculty of Agriculture, Islamic University of , Pekanbaru during 4 months, starting form June to September 2018. The design used was completely randomized factorial with 2 factors, namely Trichocompost Dose, levels $0,4,8,12 \mathrm{~g}$ Trichoderma $/ \mathrm{kg}$ compost and peat composition level: 100, 75, 50, 25\%. Parameters tested: plant height, age of tuber formation, number of leaves, number of tubers, and tuber weight. The data were statistically analyzed and the BNJ follow-up test at 5\% level. The results showed that the dose of trichocompost combined on peat had a significant effect on all observation parameters and the best treatment was 8-12 $\mathrm{g}$ trichoderma $/ \mathrm{kg}$ compost at $75 \%$ peat composition.
\end{abstract}

Keywords: Shallots, Peat Composition, Trichocompost Dosage

\begin{abstract}
ABSTRAK
Budidaya tanaman bawang merah di gambut terkendala oleh tingkat kesuburan tanah yang rendah dan salah satu cara untuk meningkatkan kandungan hara dengan pemberian trichokompos. Trichokompos merupakan bahan dari sisa tanaman yang dikomposkan dan dicampur dengan Trichoderma sp. sebagai mikroba dekomposer. Trichokompos meningkatkan kesuburan tanah (biologi, fisika dan kimia tanah). Tujuan penelitian untuk mengetahui pengaruh dosis trichokompos pada berbagai komposisi gambut terhadap hasil bawang merah. Penelitian di Lahan Penelitian Fakultas Pertanian Universitas Islam Riau selama 4 bulan, bulan Juni - September 2018. Rancangan yang digunakan Acak Lengkap Faktorial, dengan 2 faktor yaitu Dosis Trichokompos, taraf 0, 4, 8, 12 $\mathrm{g}$ tricoderma/kg kompos dan Komposisi gambut, taraf :100, 75, 50, 25\%. Parameter yang diuji: tinggi tanaman, umur terbentuk umbi, jumlah daun, jumlah umbi, berat umbi. Data dianalisis statistik dan Uji lanjut BNJ taraf 5\%. Hasil penelitian menunjukkan: dosis trichokompos dikombinasikan pada gambut berpengaruh nyata pada semua parameter pengamatan, perlakuan terbaik dosis $8-12 \mathrm{~g}$ trichoderma/kg kompos pada komposisi gambut $75 \%$.
\end{abstract}

Kata kunci: Bawang Merah, Komposisi Gambut, Dosis Trichokompos

\section{PENDAHULUAN}

Bawang merah, komoditi sayuran semusim prioritas yang harus terus dibudidayakan karena dibutuhkan setiap hari untuk bumbu masakan campuran cabai atau jenis masakan lainnya serta sebagai obat herbal. Tanaman bawang merah pada lahan gambut di provinsi Riau sudah dikembangkan walaupun masih dalam skala kecil dan pemanfaatan pekarangan rumah atau di budidayakan dalam polybag untuk pemenuhan kebutuhan keluarga saja.

Pada Data Badan Pusat Statistik (2018) tercatat bahwa tanaman bawang merah sudah dikembangkan dari tahun 2013, produktivitas yang dihasilkan masih rendah yaitu 4 ton/ha, dan Tahun 2017 produktivitas bawang merah 
menurun yaitu 3.09 ton/ha. Hasil ini lebih rendah dibandingkan dengan provinsi lain yang budidayanya juga pada lahan gambut seperti Provinsi Kalimantan Barat, Kalimantan Selatan dan Kalimantan timur yang produktivitasnya mencapai 5.54, 4.70 dan 8.14 ton/ha.

Gambut merupakan tanah marginal karena memiliki kendala biofisik yang sukar diatasi, seperti $\mathrm{pH}$ rendah $(3,0-4,5), \mathrm{Al}, \mathrm{Fe}$ dan Mn dengan kadar tinggi merupakan racun bagi tanaman, selanjutnya bahan organik yang sebagai penyusun tanah gambut terbentuk dari sisa-sisa tanaman yang belum melapuk sempurna karena kondisi lingkungan jenuh air dan miskin hara (Agus dan Subiksa, 2008).

Potensi pemanfaatan gambut yang beragam untk budidaya tanaman merupakan sumber daya penting yang harus tetap dilestarikan. Dari tahun ke tahun lahan gambut telah menjadi pusat perhatian peneliti karena fungsi dan peranannya dalam perbaikan kualitas lingkungan global tergantung bagaimana cara pengelolaan gambut tersebut.

Salah satu cara untuk meningkatkan kesuburan tanah gambut dan mencegah tanaman terserang layu fusarium dan busuk umbi adalah dengan pemberian pupuk organik, yaitu trichokompos. Trichokompos adalah bahan organik yang berasal dari sisa-sisa tanaman atau gulma yang dikomposkan, kemudian dicampur atau ditambahkan Trichoderma sp. sebagai mikroba dekomposer. Tujuan pemberian untuk mempercepat proses pengomposan dan juga memperbaiki sifat biologi, fisik, dan kimia tanah, sehingga tanaman dapat tumbuh dengan baik serta tahan terhadap serangan hama dan penyakit. Selanjutnya juga membantu penyediaan unsurhara $\mathrm{N}, \mathrm{P}$ dan $\mathrm{K}$ dalam tanah sehingga secara tidak langsung meningkatkan kualitas tanaman yang dibudidayakan (Setyowati, 2003).

\section{METODE PENELITIAN}

Penelitian dilakukan pada Lahan Pertanian Universitas Islam Riau Pekanbaru, selama 4 bulan terhitung dari bulan Juni sampai September 2018.

Bahan-bahan yang digunakan adalah bibit bawang merah Bima Brebes, trichoderma, kompos serasah jagung, pupuk NPK 16:16:16, dolomit, dithane M45. Sedangkan alat-alat untuk penelitian adalah cangkul, meteran, plat perlakuan, gembor, kamera, dan alat-alat tulis.

Rancangan penelitian ini adalah Acak Lengkap dengan 2 faktorial, yaitu Dosis Trichokompos dengan 4 taraf perlakuan 0,4 , 8, dan 12 g/kg kompos dan Komposisi Gambut dengan 4 taraf perlakuan $100,75,50,25 \%$, masing-masing terdiri dari 3 ulangan sehingga diperoleh 48 plot. Setiap plot ada 16 tanaman dan 8 tanaman dijadikan sampel. Data di analisis secara statistik dan disajikan dalam bentuk grafik.

Pelaksanaan Penelitian dimulai dari pembuatan kompos dari serasah tanaman jagung selama 3 minggu, selanjutnya kompos dicampur dengan tricoderma sesuai dengan perlakuan yaitu $0,4,8,12 \mathrm{~g}$ tricoderma $/ \mathrm{kg}$ kompos. Tricokompos dimasukkan ke dalam polybag bersamaan dengan gambut dan dibiarkan selama 7 hari setelah itu siap untuk di tanam dengan bibit bawang merah dengan kriteria umbi bibit yang berukuran sedang dengan berat kurang lebih 2,5 gram, umbi sehat, bebas dari penyakit, tidak cacat atau luka, dan umur bibit yang sudah dikeringkan selama 2 - 3 bulan. Sebelum dilakukan penanaman umbi bawang merah dipotong $1 / 3$ bagian ujung umbi, setelah itu dimasukan kedalam lobang tanam yang telah dibuat. Pemeliharaan meliputi penyiraman, penyiangan, pengendalian Hama dan Penyakit. Umbi bawang merah sudah dapat dipanen dengan kriteria daun mulai menguning dan daun mulai rebah $60-70 \%$, pangkal daun menipis. Parameter yang diamati adalah tinggi tananaman umur 10, 20, $30 \mathrm{hst}$, umur terbentuk umbi, jumlah daun, jumlah umbi dan berat umbi per umbi.

\section{HASIL DAN PEMBAHASAN}

\section{Tinggi Tanaman}

Hasil pengamatan terhadap parameter tinggi tanaman bawang merah setelah dianalisis ragam menunjukkan bahwa dosis trichokompos pada komposisi gambut terhadap pertumbuhan dan hasil bawang merah berpengaruh nyata. Rerata tinggi tanaman umur 10, 20 dan 30 hst dapat dilihat pada grafik 1, 2 dan 3 . 


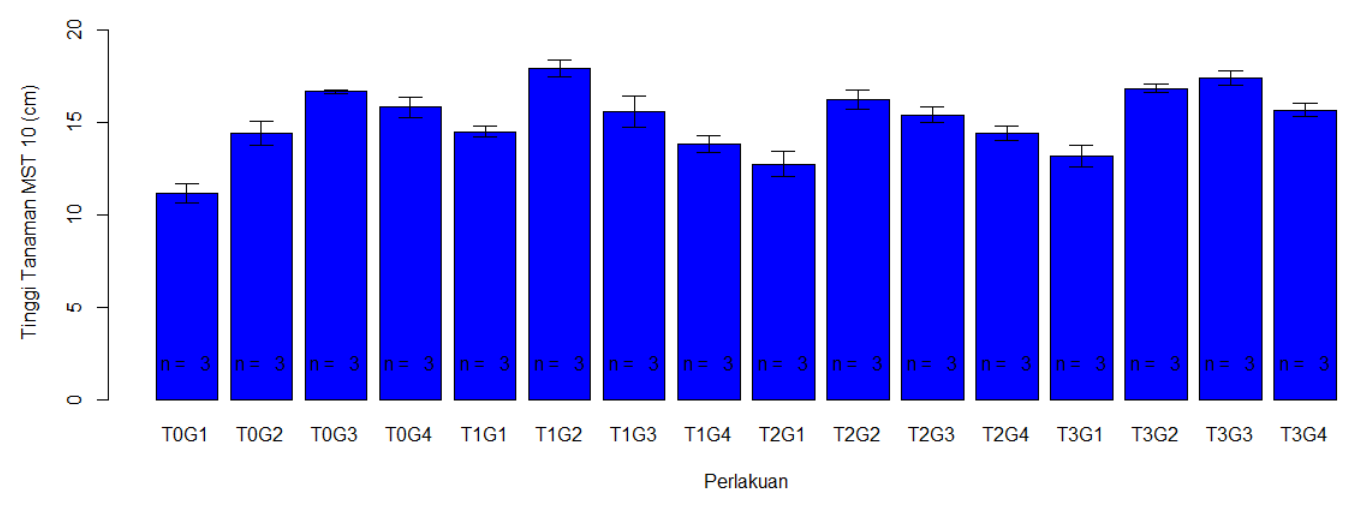

Grafik 1.Rata - rata Tinggi tanaman umur 10 hst

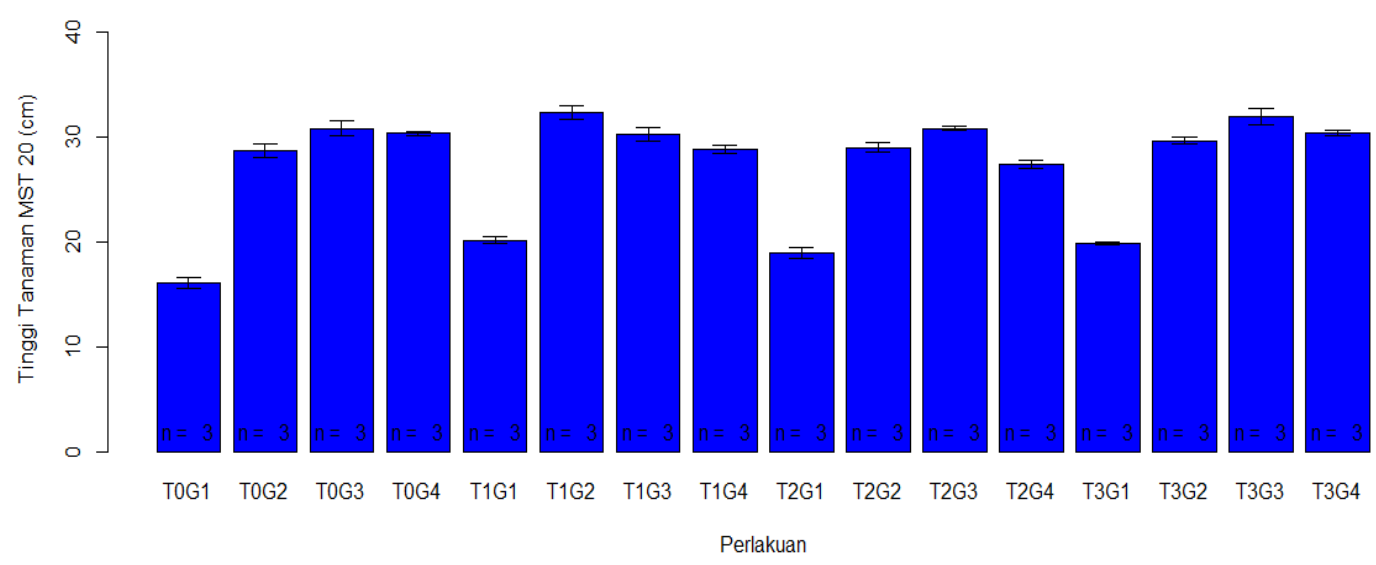

Grafik 2. Rata - rata Tinggi tanaman umur 20 hst

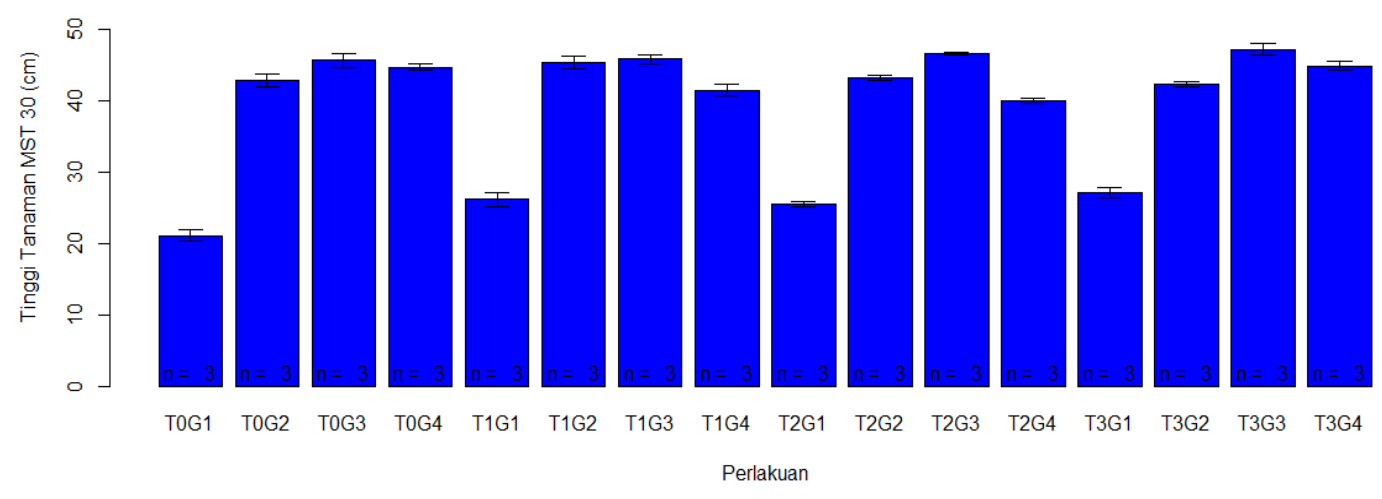

Grafik 3. Rata - rata Tinggi tanaman umur 30 hst

Tanaman bawah merah umur 10 hst sudah mampu menghasilkan tinggi tanaman diatas $11 \mathrm{~cm}$, dimana tinggi tanaman tertinggi pada perlakuan T1G2 (4 g tricoderma $/ \mathrm{kg}$ kompos dan $75 \%$ gambut : $25 \%$ trichocompos) yaitu $17,92 \mathrm{~cm}$, setiap hari terjadi penambahan tinggi tanaman $1-1,7$ $\mathrm{cm}$. sedangkan pada tanaman bawang merah umur 20 hst, tinggi tanaman terbaik pada perlakuan T1G2 yaitu $32,33 \mathrm{~cm}$, dan rata-rata penambahan tinggi tanaman berkisar $0,7-0,9$ $\mathrm{cm}$. pada umur 30 hst tinggi tanaman terbaik pada perlakuan $\mathrm{T} 1 \mathrm{G} 2$ yaitu $47,25 \mathrm{~cm}$ dan ratarata penambahan tinggi tanaman $1-1,5 \mathrm{~cm}$. Artinya penambahan tinggi tanaman setiap harinya tidak sama dan pertumbuhan menurun memasuki fase generatif atau pembesaran umbi.

Tinggi tanaman bawang merah dari awal pertumbuhan sampai umur 30 hst 
menunjukkan perkembangan yang baik, dimana tinggi tanaman terbaik mencapai 47,25 $\mathrm{cm}$ melebihi deskripsi bima brebes yaitu 44 $\mathrm{cm}$. Hal ini dikarenakan gambut komposisi $50 \%$ dengan penambahan dosis $4-12 \mathrm{~g}$ trichoderma $/ \mathrm{kg}$ kompos sudah mampu memberikan hasil yang baik artinya trichoderma dapat merombak bahan organik pada tanah gambut dan menurunkan $\mathrm{C} / \mathrm{N}$ tanah gambut perbandingan $1: 1$.

Viterbo, et al (2007) menyatakan bahwa jamur Trichoderma sp. sebagai dekomposer sangat berperan dalam proses pengomposan agar dapat menguraikan bahan organik seperti selulosa menjadi senyawa glukosa menjadi lebih baik dan lebih cepat tersedia bagi tanaman untuk pertumbuhan dan perkembangan.

Pendapat Ichwan (2007) menyatakan bahwa pemberian trichocompos pada tanaman cabai merah dapat memperbaiki sifat fisik dan biologi tanah, disamping itu trichoderma dapat pula berfungsi sebagai agen hayati dan stimulator pertumbuhan tanaman (Nurahmi,dkk, 2012). Hasil Analisis gambut sebelum dan sesudah diberi trichocompos mengalami peningkatan yaitu 3,89 menjadi 5,04 .

Parameter tinggi tanaman juga merupakan salah satu indikator pertumbuhan yang harus diketahui atau diamati, walaupun sebenarnya tidak ada korelasi dengan hasil yang diperoleh baik itu terhadap jumlah umbi, berat umbi atau lilit umbi.

\section{Umur Terbentuk Umbi (hst)}

Hasil pengamatan terhadap parameter umur terbentuk umbi bawang merah setelah dianalisis ragam menunjukkan bahwa dosis trichokompos pada berbagai komposisi gambut terhadap pertumbuhan dan hasil bawang merah berpengaruh nyata. Rerata umur terbentuk umbi bawang merah dapat dilihat pada grafik 4.

Pada grafik 4, dapat dilihat bahwa perlakuan terbaik untuk percepatan pembentukan umbi yaitu T3G1 (12 g trichoderma/kg kompos kombinasi gambut $100 \%$ ) umur 22,67 hst dan terendah perlakuan T0G1 (tanpa trichoderma $/ \mathrm{kg}$ kompos kombinasi $100 \%$ ) karena lama terbentuk umbi yaitu umur 28 hst. Tetapi jika dibandingkan dari beberapa penelitian terdahulu umur terbentuk ini lebih lambat $5-7$ hari hal ini dikarenakan karena sangat subur pertumbuhan daunnya (vegetatif) sehingga memperlambat umur pembentukan umbi dan juga panen bawang merah. Selain itu, penyebab lamanya bibit menjadi umbi juga diasumsikan karena pada saat proses pemanenan umbi bawang merah yang dijadikan bibit penanaman selanjutnya dilakukan secara serentak, padahal bisa saja belum semua umbi bawang merah yang sudah layak dipanen.

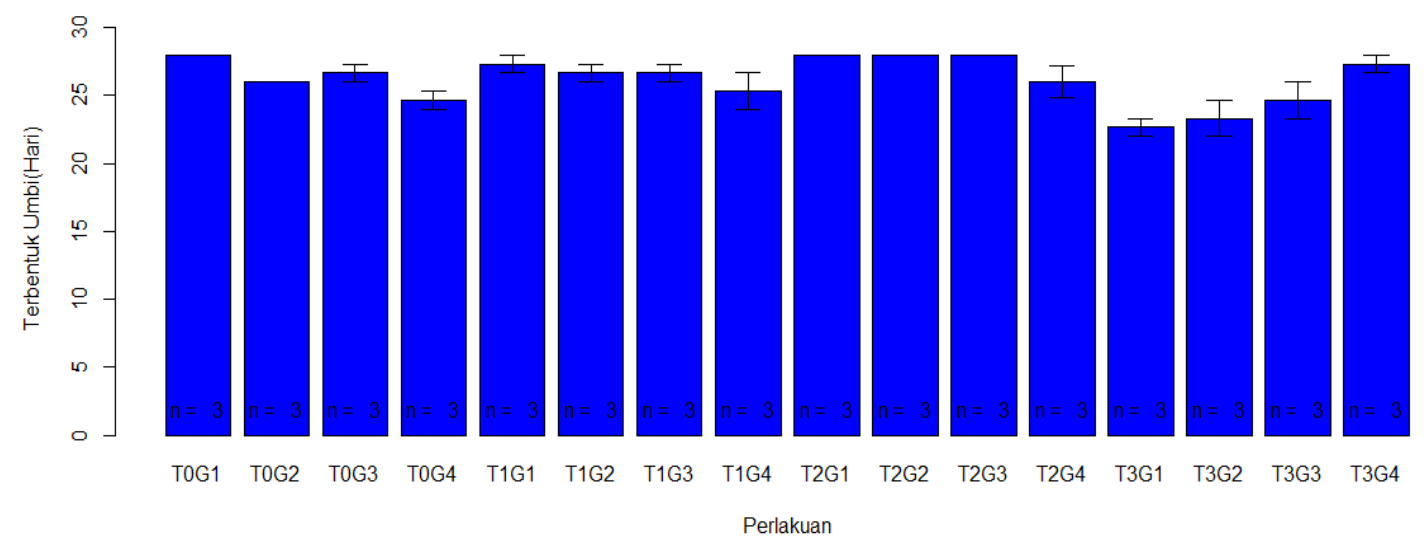

Grafik 4. Rata-rata umur terbentuk umbi bawang merah

Bawang merah untuk dikonsumsi panennya dilakukan cepat atau lambat tidak terlalu berpengaruh tetapi jika bawang merah tersebut selanjutnya dijadikan sebagai bibit periode tanaman berikutnya maka harus dari hasil panen yang sempurna dan minimal 2 bulan harus dikering anginkan untuk mengurangi kadar air dan mengetahui kualitas umbi (Sutriana dan M Nur, 2018).

Sejalan dengan pernyataan Djuariah (2004) dalam Putra, WH (2012) bahwa suatu biji daya kecambahnya sangat ditentukan oleh faktor genetis dan lingkungan serta tidak terpenuhinya unsurhara yang dibituhkan untuk mendukung perkembangan biji tersebut. 


\section{Jumlah Daun}

Hasil pengamatan terhadap parameter jumlah daun bawang merah setelah dianalisis ragam menunjukkan bahwa dosis trichokompos pada berbagai komposisi gambut terhadap pertumbuhan dan hasil bawang merah berpengaruh nyata. Rerata jumlah daun bawang merah dapat dilihat pada grafik 5

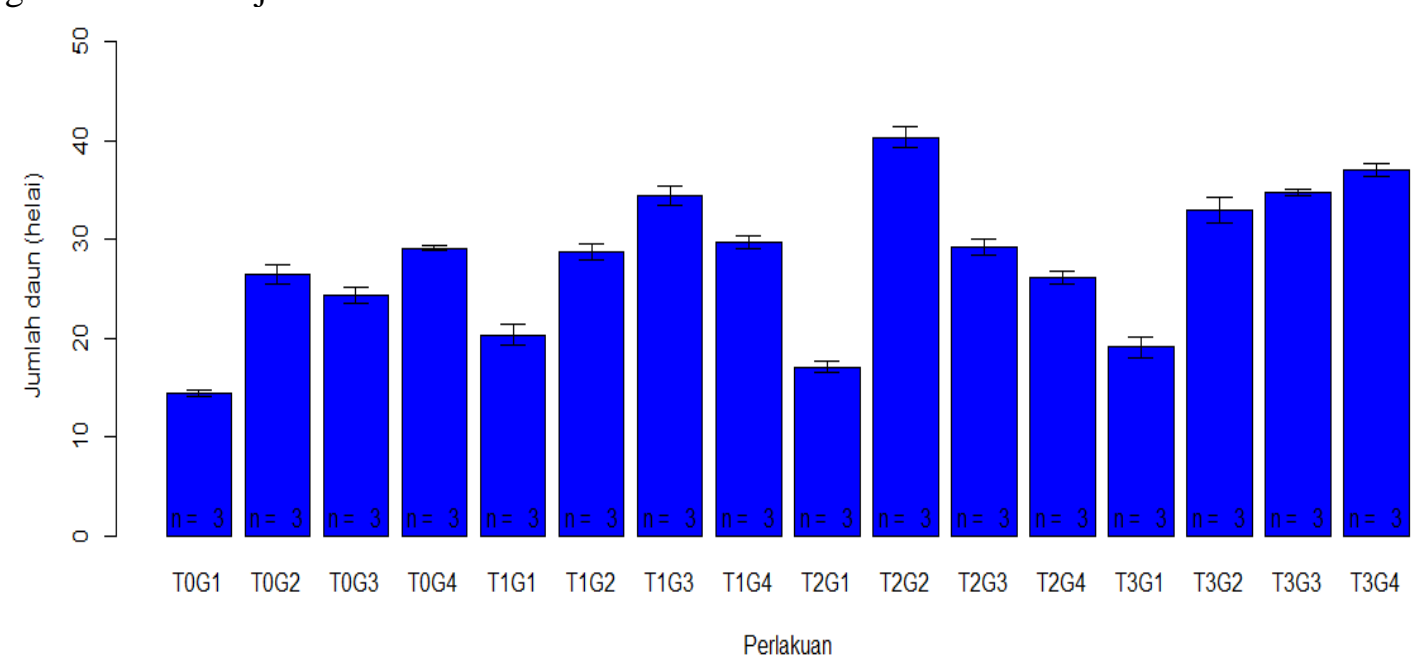

Grafik 5. Rata - rata Jumlah daun bawang merah

Pada grafik 5, dapat dilihat bahwa perlakuan terbaik untuk rata-rata jumlah daun bawang merah adalah T2G2 (8 $\mathrm{g}$ trichoderma $/ \mathrm{kg}$ kompos dan $75 \%$ gambut) 40,33 helai.

Jumlah daun yang dihasilkan sama dengan deksripsi bawang merah varietas brebes. Ini berarti bawang merah varietas brebes cocok dikembangkan pada gambut atau daerah dataran rendah seperti di Provinsi Riau. Dalam membudidayakan suatu tanaman hal penting yang harus diketahui dan dipahami adalah mengenai syarat tumbuh yang sesuai untuk tanaman tersebut.

Penggunaan pupuk trichokompos mampu meningkatkan serapan hara yang tersedia di tanah sehingga dapat berperan dalam meningkatkan hasil akumulasi fotosintat dan akan mempengaruhi proses pembentukan daun tanaman. Kemudian ditambah dengan pemberian pupuk dasar yaitu NPK 16:16:16 dengan dosis $300 \mathrm{~kg} / \mathrm{ha}$ yang diberikan pada saat tanam menyebabkan jumlah daun yang diperoleh menjadi maksimal walaupun dibudidayakan pada tanah gambut yang tergolong marginal.

Unsur Nitrogen dan fosfor berperan penting dalam proses pembentukan daun, membantu pembentukan sel-sel baru dan komponen utama penyusun senyawa organik dalam tanaman seperti asam amino,asam nukleat,klorofil, ADP dan ATP. Daun adalah morfologi dari tanaman yang digunakan sebagai tempat berlangsungnya proses fotosintesis sehingga jumlah daun sangat mempengaruhi pertumbuhan tanaman seperti berat kering umbi serta volume umbi.

Nitrogen adalah unsur penstimulus langsung prtumbuhan, prkembangan daun serta penyusun enzim dan molekul klorofil. Pada trichokompos, unsur nitrogen merupakan penyusun sel hidup dan terdapat pada seluruh bagian tanaman. Ketersediaan nitrogen yang cukup pada tanah mampu meningkatkan serapan $\mathrm{N}$ tanaman sehingga meningkatkan kandungan klorofil.Hal ini berdampak terhadap peningkatan proses fotosintesis dan pembentukan sintesis karbohidrat meningkat sehingga meningkatkan pertumbuhan vegetatif termasuk pertumbuhan tinggi tanaman dan pembentukan daun. Pendapat Nyakpa dkk.(1988), jika nitrogen terpenuhi maka sintesis klorofil, protein dan pembentukan selsel baru dapat tercapai serta mampu membentuk organ-organ seperti pembentukan daun.

\section{Jumlah Umbi Per Rumpun}

Hasil pengamatan terhadap parameter jumlah umbi per rumpun bawang merah setelah dianalisis ragam menunjukkan bahwa interaksi dan utama uji berbagai dosis trichokompos dan komposisi tanah gambut terhadap peningkatan produksi bawang merah berpengaruh nyata.Rerata jumlah umbi bawang merah dapat dilihat pada grafik 6 . 


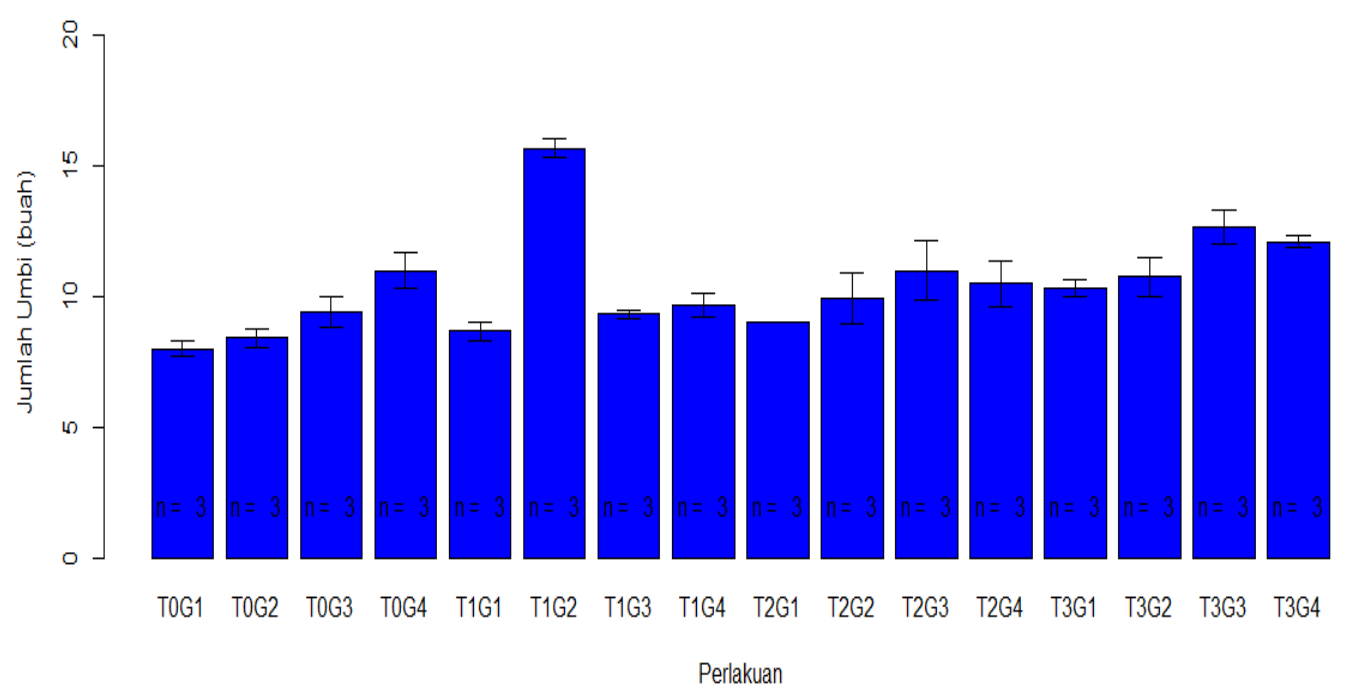

Grafik 6. Rata- rata jumlah umbi bawang merah

Pada grafik 6, dapat dilihat bahwa perlakuan terbaik untuk menghasilkan jumlah umbi terbanyak adalah T1G2 dan T3G3 masing-masing yaitu 15,66 dan 12,66 umbi/rumpun serta berbeda nyata dengan perlakuan lainnya. Jika dibandingkan dengan deksripsi hasil yang diperoleh lebih tinggi 3-5 umbi per rumpun hal ini dikarenakan pada dosis trichoderma $4-12 \mathrm{~g} / \mathrm{kg}$ kompos yang dikombinasikan dengan $25-50 \%$ gambut sudah mampu meningkatkan jumlah umbi bawang merah pada tanah gambut dan bibit bawang merah varietas brebes cocok dibudidayakan di dataran rendah.

Hasil yang diperoleh jika dibandingkan dari penelitian terdahulu juga termasuk yang terbaik ini berarti pemberian trichoderma pada kompos serasah jagung yang dikombinasikan dengan perbandingan gambut dan dosis trichokompos yang tepat mampu meningkatkan hasil bawang merah. Jumlah umbi berkorelasi dengan jumlah anakan. Semakin banyak jumlah anakan maka kemungkinan besar jumlah umbi akan banyak pula.

Penggunaan pupuk Trichokompos juga dapat membantu tanaman dalam meningkatkan serapan hara yang tersedia di tanah sehingga berperan dalam meningkatkan hasil akumulasi fotosintat dan mempengaruhi pembentukan umbi bawang merah. Menurut Berlian dan Rahayu (2004), rata-rata umbi bawang merah berkisar 2-20 tunas. Dalam perkembangan tunas vegetatif menjadi umbi, tidak diperlukan unsurhara karena tunas memanfaatkan cadangan makanan yang terdapat pada umbi (bibit), sedangkan untuk perbesaran umbi maka perlu penambahan unsurhara.

Umbi lapis pada bawang merah merupakan pangkal dari daun berubah bentuk dan fungsinya menjadi tunas baru yang selanjutnya terjadi pembesaran umbi dan tumbuh besar, dengan demikian maka dari satu umbi membentuk rumpun tanaman yang berasal dari peranakkan umbi.

\section{Berat Umbi Per Umbi}

Hasil pengamatan terhadap parameter berat umbi per umbi bawang merah setelah dianalisis ragam menunjukkan bahwa dosis trichokompos pada berbagai komposisi gambut terhadap pertumbuhan dan hasil bawang merah berpengaruh nyata. Rerata berat umbi kering per umbi bawang merah dapat dilihat pada grafik 7.

Pada grafik 7, dapat dilihat bahwa perlakuan terbaik untuk berat umbi per umbi adalah T3G2 (12 g trichoderma/kg kompos) menghasilkan berat umbi per umbi 8,04 g. Tinggi berat umbi pada perlakuan ini dikarenakan dosis trichoderma sp yang tinggi $12 \mathrm{~g} / \mathrm{kg}$ kompos dikombinasikan dengan komposisi gambut $75 \%$ sudah mampu meningkatkan berat umbi per umbi, dan juga mempengaruhi kemampuan tanah dalam menyimpan air, sehingga memudahkan akar saat pengambilan unsurhara mineral dan air untuk metabolisme tanaman. 


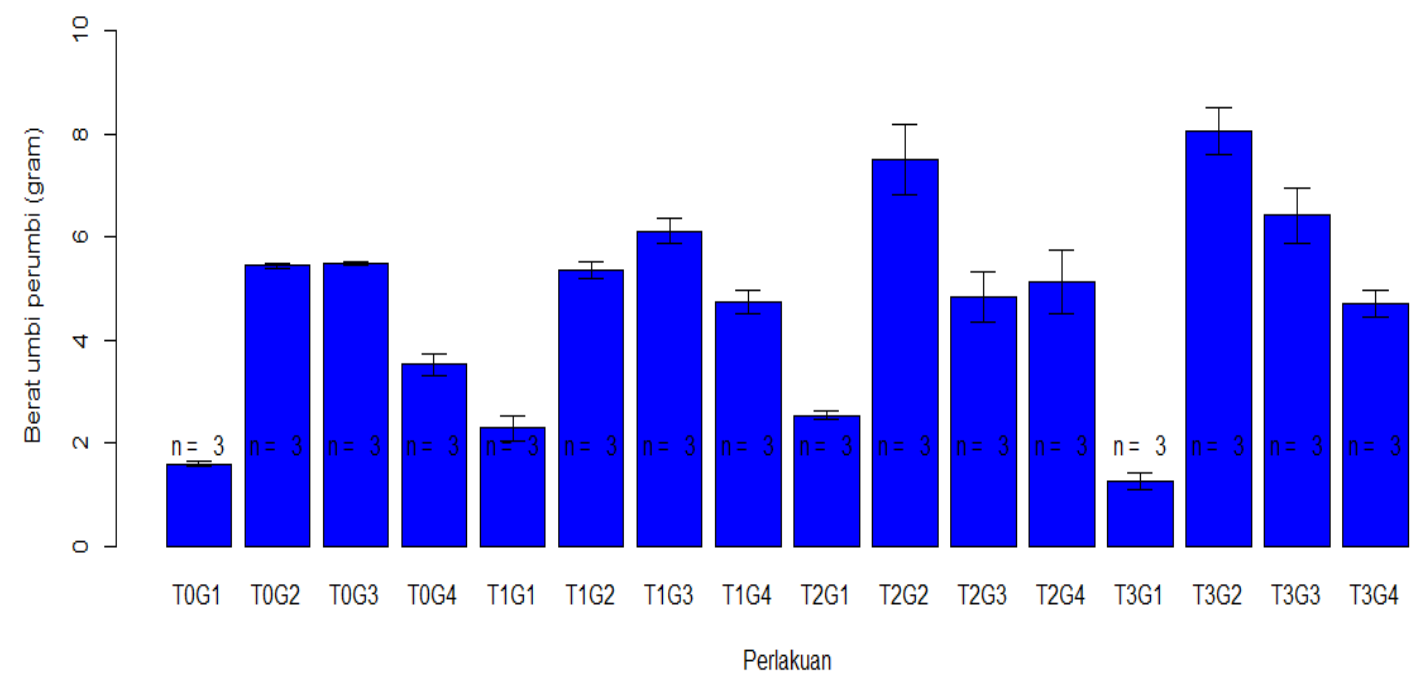

Grafik 7. Rata - rata Berat umbi per umbi bawang merah

Bahan organik yang telah diberikan Trichoderma sp dapat meningkatkan pertumbuhan dan hasil berat umbi per umbi dengan cara memperbaiki sifat fisik tanah yaitu meningkatkan pori - pori tanah (aerase tanah), memperbaiki tata udara dan air tanah sehingga sistem perkaran menjadi lebih baik. Kondisi seperti ini akan meningkatakn serapan hara terutama unsur $\mathrm{K}$ oleh akar tanaman yang akhirnya juga meningkatkan berat umbi bawang merah. Peranan K memacu translokasi hasil fotosintesis dari daun ke bagian umbi tanaman (Herlina dkk, 2016).

Bawang merah varietas brebes cocok dibudidayakan pada tanah gambut dengan catatan pemupukan dilakukan sesuai dengan teknik budidaya bawang merah di tanah gambut dan juga tidak terlepas dari peran akar yang berfungsi untuk proses penyerapan zatzat dari dalam tanah untuk ditransportasikan ke seluruh tubuh sehingga menghasilkan berat tanaman bawang merah yang meningkat pula. Pertambahan berat dipengaruhi oleh adanya proses pemanjangan sel yang diikuti oleh pembesaran sel.

\section{KESIMPULAN}

Hasil penelitian yang diperoleh dapat disimpulkan bahwa pertumbuhan dan hasil bawang merah pada perlakuan trichokompos yang dikombinasikan pada berbagai komposisi gambut berpengaruh nyata pada semua parameter pengamatan. Perlakuan terbaik dosis $8-12 \mathrm{~g}$ trichoderma $/ \mathrm{kg}$ kompos dan komposisi gambut $75 \%$.

\section{UCAPAN TERIMA KASIH}

Terimakasih disampaikan kepada Ketua LPPM yang telah mndanai penelitian ini dalam Skema Penelitian Internal Universitas Islam Riau, Dekan Fakultas Pertanian, Ketua dan Sekretaris Prodi Agroteknologi, Bapak/Ibu dosen dan mahasiswa/I Agroteknologi Angkatan 2015 yang telah membantu penelitian ini hingga selesai tepat waktu.

\section{DAFTAR PUSTAKA}

Agus, F., dan I.G. Subiksa. 2008. Lahan gambut: potensi untuk pertanian dan aspek lingkungan. Balai Penelitian Tanah. Badan Litbang Pertanian. World Agroforestry Centre, Bogor.

Berlian dan Rahayu. 2004. Bawang Merah Mengenal Varietas Unggul dan Cara Budidaya Secara Kontinyu. Penebar Swadaya. Jakarta.

Biro Pusat Statistik. 2018. Luas Panen, Produksi, Produktivitas Bawang Merah. Biro Pusat Stastistik, Jakarta.

Herlina, N. 2016. Pertumbuhan dan Produksi Bawang Merah (Allium ascalonicum L.) Dengan Pemberian Trichokompos TKKS Terfomulasi dan Pupuk Kalium di Lahan Gambut. Jurnal Photon 7(1): 1 - 9

Ichwan. 2007. Pengaruh dosis Trichokompos terhadap pertumbuhan dan hasil cabai merah. Jurnal Agronomi 11 (1): 47-50

Nurahmi, Susanna dan Rina. 2012. Pengaruh Trichoderma Terhadap Perkecambahan dan Pertumbuhan Bibit Kakao, Tomat dan Kedelai. Jurnal Floratek 7:57 - 65 
Nyakpa M.Y. Lubi M.A. Pulungan M. Amran Go Ban Hong N. Hakim. 1998. Kesuburan Tanah. Universitas Lampung Press. Lampung

Setyowati. 2003. Penurunan Penyakit Busuk Akar dan Pertubuhan Gulma Pada Tanaman Selada Yang Dipupuk Mikroba. Jurnal ilmu Pertanian Indonesia $5: 25-26$

Sutriana dan M. Nur. 2018. Aplikasi Pupuk Kompos dan Frekuensi Pemupukan NPK Dalam Meningkatkan Produksi Bawang Merah (Allium ascalonicum L) Pada Tanah Gambut. Jurnal Dinamika Pertanian 34 (3) : $201-210$.

Viterbo, A., Wiest, A., Brotman, Y., Chet, I., dan Kerneley, C. 2007. The 18mer peptaibols from Trichoderma virens elicit plant defense responses. Mol. Plant Pathol.8 (6) : 737- 746. 